Crop Breeding and Applied Biotechnology 12: 96-103, 2012

Brazilian Society of Plant Breeding. Printed in Brazil

\title{
ARTICLE
}

\section{Agrobiodiversity in Cucurbita spp. landraces collected in Rio de Janeiro assessed by molecular markers}

Marilene Hilma dos Santos ${ }^{1}$, Rosana Rodrigues ${ }^{1 *}$, Leandro Simões Azeredo Gonçalves ${ }^{1}$, Cláudia Pombo Sudré ${ }^{1}$ and Messias Gonzaga Pereira ${ }^{1}$

Received 25 February 2011

Accepted 15 November 2011

\begin{abstract}
Diversity and genetic relationship in forty landraces of Cucurbita spp. collected at small farms in Rio de Janeiro, Brazil, were analyzed by RAPD and ISSR markers, using 20 and 15 primers, respectively. Both markers were efficient to cluster the accessions separating among species, but not so much to the detection of intra-specific variability, considering the event of different pairs of accessions comprising null genetic distances observed for both markers in C. moschata. Low values observed for genetic distance among the C. moschata landraces showed that most likely genetic losses is in progress in that region of cultivation due to anthropic and market pressure, which are stimulating the small farmers to abandon their local varieties in order to use commercial seeds, including hybrids, which is causing risk of genetic erosion.
\end{abstract}

Key words: genetic resources, germplasm characterization, genetic distance, molecular characterization, on farm conservation.

\section{INTRODUCTION}

Cucurbita species play an important role in human food once they are sources of vitamin $C$, minerals and $\beta$-carotene (provitamin A) (Gwanama et al. 2001). In Brazil, the cultivation of pumpkins is largely widespread and these crops are part of the population diet in many different regions of the country (Ramos and Queiroz 2005). The germplasm of these species in different Brazilian states presents great variability, probably associated with the history and with the Brazilian colonization that included a significant immigration of African people, which introduced samples of plants belonging to different species of this family into Brazilian conditions (Moura et al. 2005). Some farmers are still cultivating and performing selections for many generations, resulting in varieties adapted to the local cultivation conditions. Nowadays, in different Brazilian regions, the cultivation of cucurbits is performed prevailingly by small farmers, which use familiar labor. These family farmers are the major responsible for the maintenance of the local varieties, from which the pumpkin cultivation, an allogamous plant, is also dependent in other regions of the world, such as Africa (Gwanama et al. 2001) and Spain (Ferriol et al. 2003a, Srivastava et al. 2009, Mendes Paula et al. 2010).
The consumer market demands horticultural products with uniformity along with specific types of fruit color, size, shape and flavor, and this consumption pattern has been compromising the landraces maintenance, since farmers are always growing plants to attend the market preferences. In general, the traditional varieties are less productive than hybrids and cultivars, although they are highly adapted to specific cultivation conditions and also a very significant repository of important genes for drought and pests resistance, for instance. The utilization of imported seeds of narrow genetic basis by the producers may endanger the existing variability. The same situation is being reported for cucurbits species, such as the watermelon germplasm in Turkey, where modern varieties are replacing local varieties due to the need of increasing profits, leading to a worry about the extinction of these genetic resources (Solmaz and Sart 2009). Also, the same concern was verified related to Lagenaria siceraria by Yetisir et al. (2008), which verified a decrease on the variability found in this another cucurbit species.

Considering the genetic erosion risk associated with the landraces in different environments, it is important to concentrate efforts on the genetic resources conservation, and one of the steps is gathering information on genetic diversity of the target species (Djé et al. 2006).

\footnotetext{
${ }^{1}$ Universidade Estadual do Norte Fluminense Darcy Ribeiro (UENF), Centro de Ciências e Tecnologias Agropecuárias, Laboratório de Melhoramento Genético Vegetal, Av. Alberto Lamego, 2000, Campos dos Goytacazes, 28.013-602, RJ, Brazil. "E-mail: rosana@uenf.br
} 
Germplasm characterization, based on morphological and agronomical descriptors, and also molecular markers, is very useful in the genetic diversity analysis (Ferriol et al. 2003b), and some cucurbit collections have been characterized using DNA markers (Gwanama et al. 2000, Ferriol et al. 2003a, b, 2004, Djé et al. 2006). Nevertheless, literature report about landraces kept for a long time by small farmers in Rio de Janeiro State was not found.

The objectives of this work were to collect fruits and seeds of Cucurbita spp. in small farms in the North of Rio de Janeiro State; to characterize the accessions through RAPD and ISSR molecular markers; to quantify the genetic divergence among collected accessions as well as to compare the markers efficiency in distinguishing the accessions.

\section{MATERIALS AND METHODS}

\section{Plant Materials}

Fruits from Cucurbita spp were collected at small farms located in several areas in the North region of Rio de Janeiro state (Brazil), comprising two locations: Campos dos Goytacazes and São João da Barra. These two counties were chosen because, traditionally, they have many small farmers that produced high amount of Cucurbita landraces. Occasionally, when mature fruit were not available yet, seeds that should be used in their next planting were collected. A total of 40 accessions were collected. Three Cucurbita moschata accessions from other Brazilian states (Rio Grande do Sul, Pernambuco and Espírito Santo), one C. moschata cultivar and one accession of Lagenaria siceraria (also collected at a farm in the same area) were included as standards.

\section{Molecular analysis}

Seeds from 45 accessions were sowed in polystyrene trays with organic substrate and 15 days after the germination, plantlets were transplanted to plastic pots. The plants were grown under greenhouse conditions. Each accession was represented by fifteen plants. Genomic DNA was extracted from young leaves (completely expanded) harvested in bulk (composed samples), mixing 12 plants for each accession. Samples were placed in liquid nitrogen and stored in ultrafreezer. Leaves were ground in liquid nitrogen and DNA was extracted by using the procedure described by Doyle and Doyle (1990), with minor modifications. The DNA concentration on the samples was estimated by analysis in agarose gel (1\%) stained with red gel, observed in ultraviolet light using the MiniBis Pro-Bio-imaging System.

\section{RAPD markers}

Sixty three random primers (Operon Tecnologies: OPA10, OPB-17, OPC-20, OPAF-09, OPAC-08, OPAC-13, OPAB-12, OPAB-18, APAA-12, OPAB-20, OPAF-07, OPAF4, OPAF-16, OPC-11, OPAW-15, OPAW-07, OPAW-10, OPAW-20, OPAW-09, OPV-06, OPAD-10, OPV-12, OPG-17, OPAF-08, OPAE-19, OPAE-17, OPAW-02, OPAB-06, OPG03, OPA-02, OPF-18, OPM-02, OPI-02, OPI-04, OPI-05, OPL-18, OPH-07, OPK-07, OPK-13, OPN-03, OPAC-16, OPH-18, OPD-17, OPN-18, OPH-16, OPH-20, OPM-18, OPL-15, OPN-04, OPJ-06, OPJ-18, OPJ-14, OPAC-07, OPF-10, OPAC-20, OPF-09, OPAC-19, OPK-19, OPK19, OPG-07, OPK-06, OPG-12 e OPAC-13) were tested, in a preliminary experiment, using samples of Cucurbita moschata, Cucurbita maxima and Cucurbita pepo (one fruit for each species) to determine their ability to detect polymorphism. Twenty primers were selected and the PCR reactions were performed according to Williams et al. (1990) (Table 1). Amplification was performed in a GeneAmp PCR System 9700 Thermal cycler (Applied Biosystems), under the following conditions: $95{ }^{\circ} \mathrm{C}$ for 1 minute, followed by 45 cycles of 1 minute at $94{ }^{\circ} \mathrm{C} ; 1$ minute at $36{ }^{\circ} \mathrm{C}$ and 2 minutes at $72{ }^{\circ} \mathrm{C}$, and the final step of 7 minutes at $72^{\circ} \mathrm{C}$ for final extension, using the fastest temperature transition way available $\left(1^{\circ} \mathrm{C} \mathrm{sec}^{-1}\right)$. Electrophoresis was carried out at $100 \mathrm{~V}$, using agarose gel at $2 \%$, for approximatedly 2 hours, and the products of amplification were visualized with red staining gel, and their polymorphism were evaluated.

\section{ISSR markers}

In order to detect polymorphism among and inside analyzed species, 18 primers were previously chosen. They had already been used by Heikal et al. (2008) and Djé et al. (2006): DBD(AC) $)_{7}$; GAG (CAA) $)_{5}$; (GA) ${ }_{8} \mathrm{~T}$; (AG) ${ }_{8} \mathrm{~T}$; (AG) ${ }_{8} \mathrm{G}$; $(\mathrm{AG})_{8} \mathrm{YT} ;(\mathrm{AC})_{8} \mathrm{G} ; \mathrm{DD}(\mathrm{CGA})_{5}$; $\mathrm{VHV}(\mathrm{GT})_{7} \mathrm{G} ;(\mathrm{GA})_{8} \mathrm{YC}$; $(\mathrm{CT})_{8} \mathrm{TG} ;(\mathrm{CT})_{8} \mathrm{AG} ;(\mathrm{CT})_{8} \mathrm{GC} ;(\mathrm{CA})_{6} \mathrm{AC} ;(\mathrm{CA})_{6} \mathrm{GT} ;(\mathrm{CA})_{6} \mathrm{AG}$ and (CA) $)_{6}$ GG. Four other primers were randomly chosen: $(\mathrm{CT})_{8} \mathrm{RC}$; (GA) $)_{9}$; AGC $_{5} \mathrm{AY}$ and (AGC) ${ }_{5} \mathrm{R}$. Once they had been tested, the 15 best primers were selected to be used for amplification of polymorphic loci (Table 1).

The amplification reactions were performed at a final volume of $20 \mu \mathrm{L}$, containing the following reagents and their respective final concentrations: $5 \mathrm{ng}$ of genomic DNA; $0.4 \mu \mathrm{M}$ of primer; $2 \mathrm{nM}$ of $\mathrm{Mg} \mathrm{Cl}_{2} ; 100 \mu \mathrm{M}$ of each dNTP; $0.6 \mathrm{U}$ of Taq DNA polymerase; $5 \%$ of DMSO and buffer enzyme 1X. Amplification protocol to the dinucleotides was carried out according to Yao et al. (1999). The amplification protocol to trinucleotides was carried out according to Djé et al (2006). Amplification products (bands) were separated through agarose 
Table 1. RAPD and ISSR primers, polymorphic, monomorphic and total band numbers generated from genetic divergence among 44 Cucurbita spp accessions e one Lagenaria siceraria accession

\begin{tabular}{|c|c|c|c|c|}
\hline \multirow[b]{2}{*}{ Primers } & \multirow{2}{*}{$\begin{array}{c}\text { Sequence } \\
\left(5^{\prime}-3^{\prime}\right)\end{array}$} & \multicolumn{2}{|c|}{ Bands } & \multirow[b]{2}{*}{ Total } \\
\hline & & $\begin{array}{c}\text { Mono- } \\
\text { morphic }\end{array}$ & $\begin{array}{c}\text { Poly- } \\
\text { morphic }\end{array}$ & \\
\hline \multicolumn{5}{|l|}{ RAPD } \\
\hline OPA 10 & GTGATCGCAG & 0 & 11 & 11 \\
\hline OPB 17 & AGGGAACGAG & 1 & 6 & 7 \\
\hline OPH 20 & GGGAGACATC & 1 & 6 & 7 \\
\hline OPL 18 & ACCACCCACC & 0 & 7 & 7 \\
\hline OPK 07 & AGCGAGCAAG & 0 & 9 & 9 \\
\hline OPG 17 & ACGACCGACA & 0 & 12 & 12 \\
\hline OPN 04 & GACCGACCCA & 0 & 4 & 4 \\
\hline OPAA 10 & TGCTCGGGTG & 0 & 9 & 9 \\
\hline OPAA 12 & GGACCTCTTG & 0 & 8 & 8 \\
\hline OРАВ 03 & TGGCGCACAC & 0 & 3 & 3 \\
\hline OPAB 10 & ТТСССТСССА & 0 & 6 & 6 \\
\hline OPAC 07 & GTGGCCGATG & 1 & 12 & 13 \\
\hline OPAD 10 & AAGAGGCCAG & 0 & 5 & 5 \\
\hline OPAE 17 & GGCAGGTTCA & 0 & 12 & 12 \\
\hline OPAE 19 & GACAGTCCCT & 0 & 5 & 5 \\
\hline OPAF 07 & GGAAAGCGTC & 0 & 3 & 3 \\
\hline OPAF 16 & TCCCGGTGAG & 1 & 4 & 5 \\
\hline OPAW 07 & AGCCCССAAG & 0 & 4 & 4 \\
\hline OPAW 09 & ACTGGGTCGG & 0 & 6 & 6 \\
\hline OPAW 10 & GGTGTTTGCC & 0 & 5 & 5 \\
\hline Total & & 4 & 137 & 141 \\
\hline \multicolumn{5}{|l|}{ ISSR } \\
\hline (AC)8G & & 1 & 9 & 10 \\
\hline (AG)8T & & 1 & 12 & 13 \\
\hline (AG)8YT & & 2 & 8 & 10 \\
\hline (CA)6GT & & 0 & 7 & 7 \\
\hline (CA)6GG & & 0 & 6 & 6 \\
\hline (CA)6AG & & 0 & 12 & 12 \\
\hline (CT)8TG & & 0 & 3 & 3 \\
\hline (CT)8AG & & 0 & 11 & 11 \\
\hline (CT)8GC & & 1 & 5 & 6 \\
\hline $\mathrm{DBD}(\mathrm{AC}) 7$ & & 0 & 8 & 8 \\
\hline (GA)8T & & 2 & 9 & 11 \\
\hline (GA)8YC & & 2 & 10 & 12 \\
\hline VHV(GT)7G & & 2 & 10 & 12 \\
\hline DD(CGA)5 & & 0 & 10 & 10 \\
\hline GAG(CAA)5 & & 0 & 6 & 6 \\
\hline Total & & 11 & 126 & 137 \\
\hline
\end{tabular}

gel electrophoresis with $2 \%$, dyed using a red gel and placed under UV light to view the products. Gels image were captured to later analysis.

\section{Data analysis}

Data obtained through visual evaluation of more evident and consistent bands in the studied accessions were used to construct a matrix of data. DNA fragments were scored as present (1) or absent (0). After the exclusion of monomorphic markers, the genetic dissimilarity among Cucurbita spp. accessions was estimated. The dissimilarity matrix was built through the software Genes (Cruz 2006) and the dendrograms generated with the support of the R program (http:// www.r-project.org). In order to accomplish the dissimilarity matrix, the arithmetic complement of Jaccard was used, as suggested by Meyer et al (2004). Cluster analysis carried out from the data of this matrix were performed through the hierarchical method Unweighted Paired Group Method using Arithmetic averages (UPGMA). The clustering was also tested by bootstrap analysis using the software DBOOT (Coelho 2001) with 1,000 iterations. The matrices obtained through the RAPD and ISSR markers were compared by the Mantel test, based on 1,000 simulations.

\section{RESULTS AND DISCUSSION}

At the 50 visited properties, 37 accessions of $C$. moschata were collected, indicating a predominance of this species in the sampled regions while only three accessions of $C$. maxima, one of $C$. pepo and one of $L$. siceraria were found. During the collection, a wide genotypic variability for size, shape and coloring of fruits could be observed (Figure 1). As pointed out by Vencovsky (1987), in any circumstance, one should collect seeds from the largest possible number of parental plants, taken at random. Also, the author recommends that each researcher responsible for collecting seeds should decide, at the moment of the collection, if strategies to reach the ideal representativeness are feasible, considering the time and the resources available for sampling. Sudré et al. (2011) demonstrated that there is an important difference between strategies for collecting allogamous samples recommended in literature and what one can achieve in practical terms.

The 20 RAPD primers amplified 141 bands in total, out of which 137 were polymorphic bands (97\%) and only four monomorphic (3\%). On average, each primer generated 6.85 polymorphic marks (Table 1 ). Gwanama et al. (2000), using 16 RAPD primers to study genetic diversity among 31 Cucurbita moschata genotypes, observed an average of nine fragments per primer. In total, 144 fragments were 


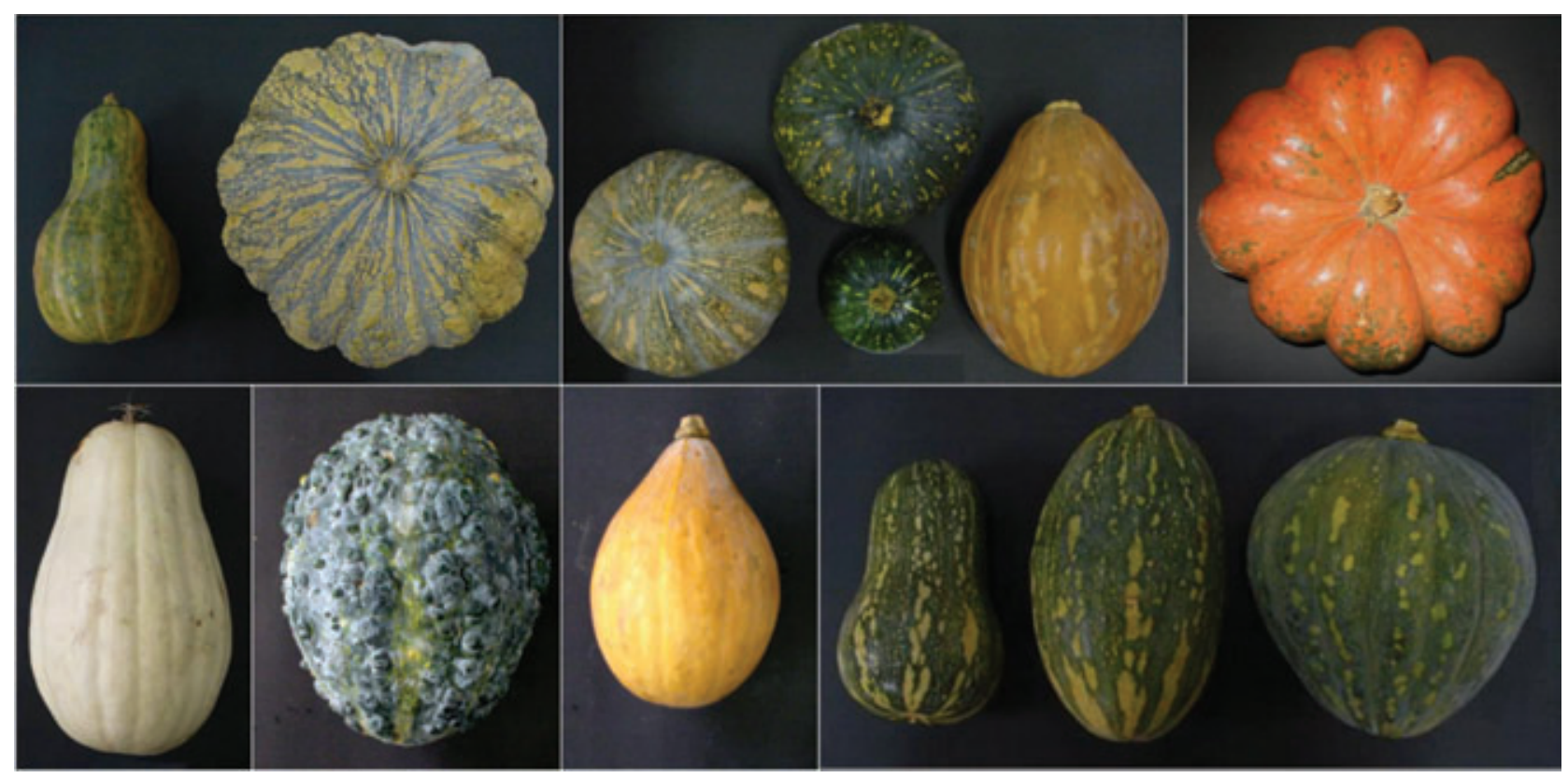

Figure 1. Variability sample observed in Cucurbita spp. and Lagenaria sp. fruits collected at several small farms in two counties (Campos dos Goytacazes and São João da Barra) in Rio de Janeiro, Brazil.

generated, of which 39 (23\%) were polymorphic. Nevertheless, it must be highlighted that in the work of Gwanama et al. (2000) only C. moschata accessions were studied, which probably caused a lower level on the detection of polymorphism, since it was a study on intra-specific diversity. On the other hand, Ferriol et al. (2003b) analyzing 19 Cucurbita maxima accessions, two of Cucurbita ficifolia, two of Cucurbita pepo, two of Cucurbita moschata and two of Lagenaria siceraria comprising 21 RAPD primers, obtained 92 fragments, out of which 52, corresponding to $57 \%$, were polymorphic. The primers generated from two to 10 fragments per primer, an average of 4.4 bands.

Accessions of different species, C. moschata, C. maxima and $C$. pepo, could be distinguished by means of the presence or absence of certain specific fragments amplified by the primer OPK 07. A similar result was found by Heikal et al. (2008), who identified a RAPD primer (OPA 02) that separated species of the Cucurbita genus (C. maxima, C. pepo and C. moschata). RAPD markers were also used successfully to estimate genetic diversity and inter-relation among C. melo coming from different regions of Asia (Tanaka et al. 2007).

The analysis of the dissimilarity matrix generated by the Jaccard index revealed that the accessions that showed greatest distances were UENF 1852 (C. maxima) and UENF 1894 ( $L$. siceraria), being a distance of 0.8947 , while the accessions UENF 1860 and UENF 1874, both of C. mos- chata, showed null genetic distance. The average distance obtained among the accessions was $0.2445( \pm 0.0232)$ (Table 2). Considering only C. moschata accessions, the greatest recorded distance was 0.2878 , between the UENF 1854 and UENF 1866 accessions, from Campos dos Goytacazes and São João da Barra, respectively.

Table 2. Comparing data from RAPD and ISSR markers used to assess genetic divergence among 44 Cucurbita spp. and one Lagenaria siceraria accessions

\begin{tabular}{|c|c|c|}
\hline \multirow{2}{*}{ Characteristics } & \multicolumn{2}{|c|}{ DNA Marker } \\
\hline & RAPD & ISSR \\
\hline Number of primers & 20 & 15 \\
\hline Total bands observed & 141 & 137 \\
\hline Polymorphic bands & 137 & 126 \\
\hline Monomorphic bands & 04 & 11 \\
\hline Polymorphic band/primer & 6.85 & 8.40 \\
\hline Larger distance $^{1}$ & 0.8947 & 0.8316 \\
\hline Smallest distance ${ }^{2}$ & 0.00 & 0.00 \\
\hline Mean genetic distance & $0.2445( \pm 0.0232)$ & $0.1476( \pm 0.0256)$ \\
\hline
\end{tabular}

${ }^{1}$ Between UENF 1894 and UENF 1852 accessions for RAPD; for ISSR larger distance between UENF 1894 and UENF 1886;

${ }^{2}$ Null distances observed between UENF 1860 e UENF 1874 accessions for RAPD and also for the following pairs of accessions considering ISSR: UENF $1895=$ UENF $1893=$ UENF $1892=$ UENF $1890=$ UENF $1885=$ UENF $1883=$ UENF $1881=$ UENF $1880=$ UENF $1874=$ UENF $1873=$ UENF $1871=$ UENF $1870=$ UENF 1867 = UENF 1865 = UENF 1861 = UENF 1855 = UENF 1858; UENF 1888 $=$ UENF 1887 = UENF 1869 = UENF 1884; UENF 1891 = UENF $1889=$ UENF $1882=$ UENF $1879=$ UENF $1877=$ UENF $1876=$ UENF $1875=$ UENF $1866=$ UENF 1863 = UENF 1862 = UENF 1853 = UENF 1854; UENF 1859 = UENF 1864. 
In view of the abrupt change point at the distance of 0.40 , four clusters were detected by UPGMA (Figure 2). Accessions were separated in the respective clusters according to their species (C. maxima, $C$. moschata, C. pepo and L. siceraria). The L. siceraria accession (UENF 1894) was arranged in cluster I. With the exception of the primers OPL18, OPAD10, OPAF07, OPN4, OPH20, OPAW09, and OPAW07, all other primers amplified specific fragments to this species, ranging from one to four bands per primer.

Cluster II gathered three C. maxima accessions, UENF 1882, UENF 1852, and UENF 1857. This cluster obtained $41.27 \%$ polymorphic and $58.73 \%$ monomorphic bands. Among monomorphic bands, 17 (45.94 \%) were proper to the C. maxima species. With the exception of primers OPAC07, OPAD10, OPAE19, OPAF07, OPH20, OPAA10 and OPAW07, all the others amplified one or two specific fragments.

As to the C. pepo species (UENF 1856), allocated separately in the third group, 20 specific fragments were counted (29\%), ranging from one to four bands per primer. The primers OPAF16, OPAB03, OPAD10, OPAE19, OPB17 and OPAW10 did not produce amplified products that could contribute to differentiate the $C$. pepo accessions from other species. Forty C. moschata accessions were gathered on cluster IV.

Using the 15 primers of the ISSR type previously selected, 137 amplification products were registered. One hundred and twenty six (126) polymorphic (92\%) and 11 monomorphic bands (8 \%) were obtained. On average, 8.4 polymorphic bands per primer were observed. The number of amplified fragments per primer ranged from 3 to 13 (Table 1).

The Jaccard dissimilarity index showed that the UENF 1886 (C. maxima) and UENF 1894 (L. siceraria) were the most distant accessions, comprising a distance of 0.8316 . The average distance among the accessions

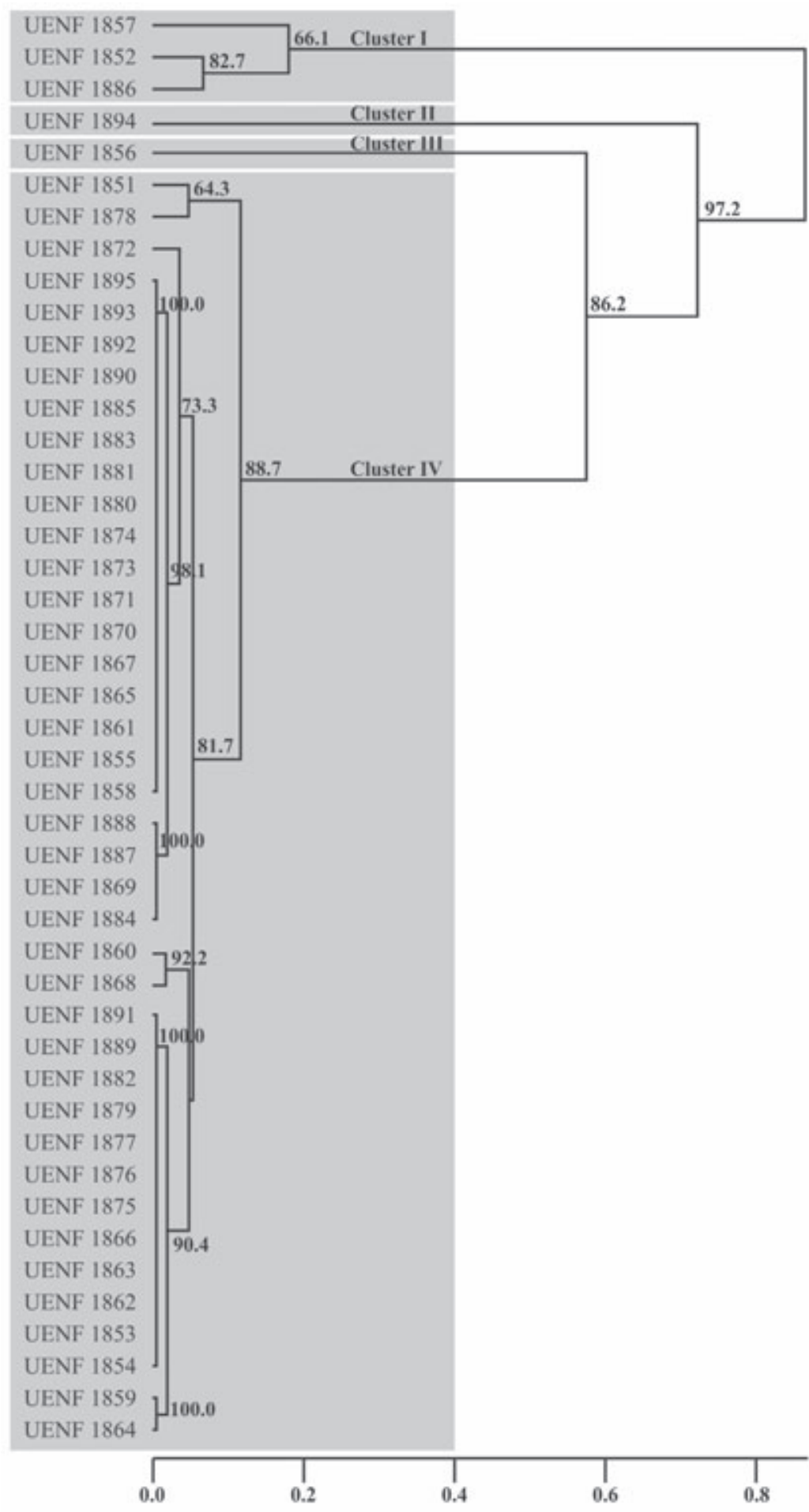

Figure 2. UPGMA dendrogram of the genetic relationship among 44 Cucurbita spp and one Lagenaria siceraria accessions collected in Rio de Janeiro State, Brazil, based on RAPD. Bootstrap values are given at the corresponding node for each cluster. 


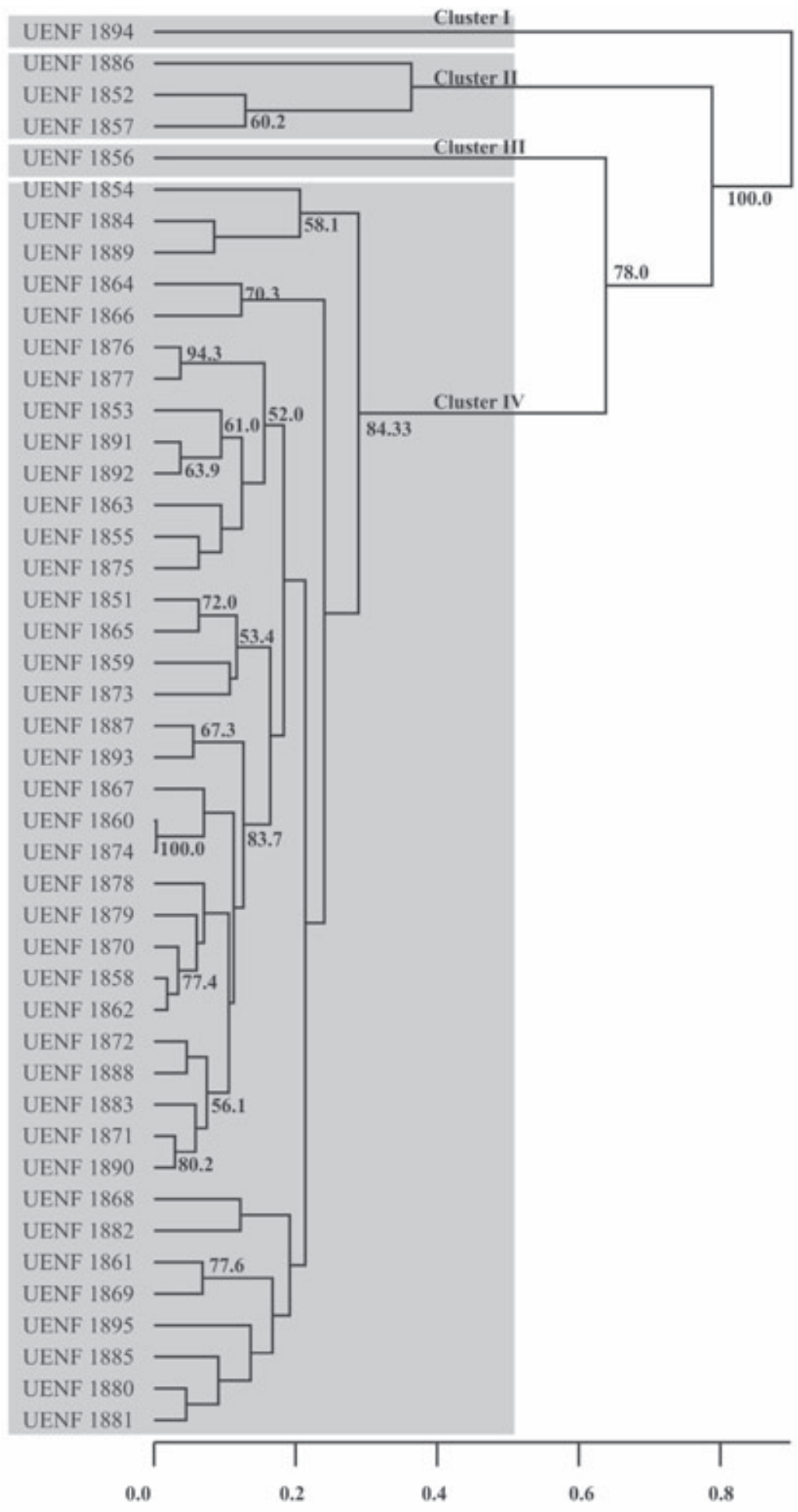

Figure 3. UPGMA dendrogram of the genetic relationship among 44 Cucurbita spp and one Lagenaria siceraria accessions collected in Rio de Janeiro State, Brazil, based on ISSR. Bootstrap values are given at the corresponding node for each cluster. was 0.1476 ( \pm 0.0256$)$ (Table 2). Except for UENF 1856, UENF 1851, UENF 1878, UENF 1872, UENF 1860 and UENF 1868 accessions, all other C. moschata accessions, collected at different farms and sites, presented null distances raising the hypothesis of possible duplicates. However, this result was not observed neither by means of morphological characterization nor by RAPD markers, which, on the contrary, showed meaningful differences on the phenotype and polymorphism as to the size of the bands.

The estimate of the correlation between the genetic distances achieved by RAPD and ISSR markers was 0.92 , with probability p $<0.001$ by the Mantel test $(10,000$ permutations), indicating that there is a pattern of association between the results achieved by these two analytical procedures in the discrimination of the accessions. Behera et al. (2008), who worked with Momordica charantia L. accessions, another Cucurbitacea species, collected in many regions of India, obtained a correlation of 0.70 between data from RAPD and ISSR.

The abrupt change point at the distance of 0.20 allowed the constitution of four clusters by the UPGMA (Figure 3). Cluster I comprised three $C$. maxima accessions (UENF 1857, UENF 1852 and UENF 1886), which presented $20.34 \%$ of polymorphic bands and 47 monomorphic. Fragments proper to these species were amplified by all the markers used in this work, ranging from one to four bands, except for (AG) ${ }_{8} \mathrm{YT}$ and VHV (GT) $)_{7} \mathrm{G}$ dimers.

Cluster II allocated the $L$. siceraria, UENF 1894, out of which $45 \%$ of characteristic bands of this species was observed (19 fragments) and amplified by primers: (AC) ${ }_{8} \mathrm{G},(\mathrm{GA})_{8} \mathrm{~T}, \mathrm{GAG}(\mathrm{CAA})_{5}$, $(\mathrm{AG})_{8} \mathrm{~T},(\mathrm{CT})_{8} \mathrm{AG},(\mathrm{CA})_{6} \mathrm{AG},(\mathrm{AG})_{8} \mathrm{YT}$ and $\operatorname{VHV}(\mathrm{GT})_{7} \mathrm{G}$. C. pepo accession, UENF 1856, formed the third cluster. One to four specific bands were amplified by most primers, except for (AC) $)_{8} \mathrm{G}, \mathrm{DD}(\mathrm{CGA})_{5}$, (GA) $)_{8} \mathrm{~T}$, $(\mathrm{CT})_{8} \mathrm{GC}, \mathrm{VHV}(\mathrm{GT})_{7} \mathrm{G}$ and $\mathrm{DBD}(\mathrm{AC})_{7}$. 
The 40 C. moschata accessions formed cluster IV, and presented low genetic variability intra-group. Only five ISSR primers amplified polymorphic bands for C. moschata accessions, two trimers, DD(CGA) $)_{5}$ and (GAG(CAA) 5 , as well as three dinucleotides (GA) ${ }_{8} \mathrm{~T}(\mathrm{CT})_{6} \mathrm{GT}$, accomplishing $13.43 \%$ polymorphic fragments (nine bands).

RAPD and ISSR markers were efficient to cluster the accessions separating among species, but they did not present such efficiency in detection of intra-specific variability, considering the event of different pairs of accessions comprising null genetic distances observed for both markers in C. moschata. A complementary characterization considering morphological and agronomical descriptors could be useful to validate (or not) the presence of duplicates among these landraces. Strategies of joint analysis of continued and discrete data, such as the Ward-MLM analysis procedure (Franco et al. 1998) have been allowing higher accuracy on estimates of genetic diversity among accessions (Gonçalves et al. 2009, Sudré et al. 2010). In some cases, a better discrimination of the accessions can be reached using morphological and agronomical characterization, although using these descriptors mean spending more time and financial resources. Besides, these characterizations require field experiments in which plants should be managed for a long period. However, in some cases, it may be enough to assure a precise quantification of genetic diversity, as verified by Sudré et al. (2010) to Capsicum genus.

According to our preliminary research, more recently, the small farmers, trying to get a commercially more acceptable product, sometimes buy seeds in another state from other small farmers and mix these seeds with their own landraces. This is happening especially with C. moschata, and sometimes the fruits are bought at the market to extract seeds to cultivation. These fruits sold at the market are deriving from different regions of Brazil, which already reveals the potential of genetic erosion on these local populations. Be- sides, it was found out that the producers keep the practice of exchanging seeds, which may contribute to reduce the genetic diversity among planted accessions, since all farmers, in the end, are planting the same genotypes. Another fact that must be mentioned is that, in general, the same name is given to phenotypically very distinct local varieties, causing a lack of precision on the accession identification.

In Rio de Janeiro State, most of crop production is carried out by small farmers which are responsible for most of vegetable crops commercialized in local markets. Competition for yield and quality of their products at the market leads these producers to use genotypes available, thus discarding the landraces, which compromises the conservation of these important genetic resources. Genetic diversity component managed by traditional populations as well as by family farmers, kept in the field, is the result of a long and diverse selection process, adjusted to local reality. Because of the landraces variability relevance, it is necessary to apply efforts to achieve their preservation.

As verified to other species of economic importance, only through the implementation of collecting activities, the characterization and evaluation of these accessions, it will be possible to maintain the genetic variability of the genus (Cucurbita moschata, Cucurbita maxima and Cucurbita pepo) and the availability of this variability to the Cucurbita breeding programs. Also, our results indicated that, considering time and cost, the RAPD was more useful and appropriate to be used with local varieties tested when compared to ISSR, which detected many null genetic distances.

\section{ACKNOWLEDGEMENTS}

The authors thank Faperj (Fundação Carlos Chagas Filho de Amparo à Pesquisa do Estado do Rio de Janeiro) and $\mathrm{CNPq}$ (Conselho Nacional de Desenvolvimento Científico e Tecnológico) for financial support this research.

\section{Agrobiodiversidade em variedades locais de Cucurbita spp. coletadas no Rio de Janeiro avaliada por marcadores moleculares}

Resumo - Divergência genética entre 40 variedades locais de Cucurbita spp coletada em propriedades rurais no Rio de janeiro foi analisada por marcadores RAPD e ISSR usando 20 e 15 iniciadores, respectivamente. Ambos os marcadores foram eficientes em promover a separação entre as espécies, mas não tanto para a detecção de variabilidade intra-específica, considerando o caso de diferentes pares de acessos compreendendo distâncias genéticas nulas observadas para ambos os marcadores em C. moschata. Baixos valores foram registrados para distância genética entre variedades locais de C. moschata sugerindo que a erosão genética pode estar ocorrendo na região de cultivo devido, entre outros fatores, à pressão antrópica e a exigências do mercado consumidor, que estimulam os pequenos produtores a trocarem suas variedades locais por híbridos comerciais.

Palavras-chave: recursos genéticos, caracterização de germoplasma, distância genética, caracterização molecular, conservação on farm. 
MH Santos et al.

\section{REFERENCES}

Behera TK, Singh AK and Staub JE (2008) Comparative analysis of genetic diversity in Indian bitter gourd (Momordica charantia L.) using RAPD and ISSR markers for developing crop improvement strategies. Scientia Horticulturae 115: 209-217.

Coelho ASG (2001) DBOOT. Avaliação dos erros associados a estimativas de distância/similaridade genéticas através do procedimento de bootstrap com número variável de marcadores, versão 1.1. Departamento de Biologia Geral, Universidade Federal de Goiás.

Cruz C D (2006) Programa Genes: análise multivariada e simulação. Editora UFV, Viçosa, 175p.

Djé Y, Tahi GC, Zoro Bi IA, Malice M, Baudoin JP and Bertin P (2006) Optimization of ISSR for African edible-seeded Cucurbitaceae species' genetic diversity analysis. African Journal of Biotechnology 5: 83-87.

Doyle JJ and Doyle JL (1990) Isolation of plant DNA from fresh tisssue. Focus 2: 13-15.

Ferriol M, Picó B and Nuez F (2003a) Genetic diversity of a germplasm collection of Cucurbita pepo using SRAP and AFLP markers. Theoretical Applied Genetics 107: 271-282.

Ferriol M, Picó B and Nuez F (2003b) Genetic diversity of some accessions of Cucurbita maxima from Spain using RAPD and SBAP markers. Genetic Resources and Crop Evolution 50: 227-238.

Ferriol M, Picó B and Nuez F (2004) Morphological and molecular diversity of a collection of Cucurbita maxima landraces. Journal of the American Society Horticultural Science 129: 60-69.

Franco J, Crossa J, Villasenõr J, Taba S and Eberhart SA(1998) Classifying genetic resources by categorical and continuous variables. Crop Science 38: 1688-1696.

Gonçalves LSA, Rodrigues R, Amaral Júnior AT, Karasawa M and Sudré CP (2009) Heirloom tomato gene bank: assessing genetic divergence based on morphological, agronomic and molecular data using a Ward-modified location model. Genetics and Molecular Research 8: $364-374$

Gwanama C, Botha AM and Labuschagne MT (2001) Genetic effects and heterosis of flowering and fruit characteristics of tropical pumpkin. Plant Breeding 120: 271-272.

Gwanama C, Labuschagne MT and Botha AM (2000) Analysis of genetic variation in Cucurbita moschata by random amplified polymorphic DNA (RAPD) markers. Euphytica 113: 19-24.

Heikal AH, Abdel-Razzak HS and Hafez EE (2008) Assessment of genetic relationships among and whitin Cucurbita species using RAPD e ISSR markers. Journal of Applied Sciences Research 4: 515-525.
Mendes Paula TO, Gonçalves LSA, Amaral Júnior AT, Oliveira EC, Silva VQR, Scapim CA and Lopes AD (2010) Magnitude of the genetic base of commercial popcorn and in recommendation in Brazi. Crop Breeding and Applied Biotechnology 10: 289-297.

Meyer AS, Garcia AAF, Souza AP and Souza Júnior CL (2004) Comparison of similarity coefficients used for cluster analysis with dominant markers in maize (Zea mays L.). Genetics and Molecular Biology 27: 83-91.

Moura MCCL, Queiroz MA, Gutman SM, Silva SL, Machado KKG and Conceição Filho JF (2005) Variedades tradicionais e variabilidade genética de hortaliças - riquezas Maranhenses. In Moura MCCL (org.) Recursos genéticos de hortaliças - riquezas naturais. Instituto Interamericano de Cooperação para a Agricultura, São Luís, p. 79-98

Ramos SRR and Queiroz MA de (2005) Recursos Genéticos de abóbora no Nordeste brasileiro. In Moura MCCL (org.) Recursos genéticos de hortaliças - riquezas naturais. Instituto Interamericano de Cooperação para a Agricultura, São Luís, p. 99-116

Solmaz I and Sart N (2009) Characterization of watermelon (Citrullus lanatus) acessions collected from Turkey for morphological traits. Genetic Resources and Crop Evolution 56: 173-188.

Srivastava R, Shukla S, Soni A and Kumar A (2009) RAPD-based genetic relationships in different Bougainvillea cultivars. Crop Breeding and Applied Biotechnology 9: 154-163.

Sudré CP, Gonçalves LSA, Rodrigues R, Amaral Júnior AT, Riva-Souza EM and Bento CS (2010) Genetic variability in domesticated Capsicum spp. as assessed by morphological and agronomic data in mixed statistical analysis. Genetics and Molecular Research 9: 283-294

Sudré CP, Rodrigues R, Gonçalves LSA, Martins ER and Bento CS (2011) Coleta, caracterização e divergência fenotípica de frutos de fava-d'anta. Revista Caatinga 24: 1-8.

Tanaka K, Nishitani A, Akashi Y, Sakata Y, Nishida H, Yoshino H and Kato K (2007) Molecular characterization of South and East Asian melon, Cucumis melo L., and the origin of Group Conomon var. makuwa and var. conomon revealed by RAPD analysis. Euphytica 153: 233-247.

Vencovsky R (1987) Tamanho efetivo populacional na coleta e preservação de germoplasmas de espécies alógamas. IPEF 35: 79-97.

Williams JGK, Kubelik AR, Livak KJ, Rafalski JA and Tingey SV (1990) DNA polymorphisms amplified by arbitrary primers are useful as genetic markers. Nucleic Acids Research 18: 6531-6535.

Yao Y, Ban M and Brandle J (1999) A genetic linkage map for Stevia rebaudiana. Genome 42: 657-661. 